\title{
Trichoderma virens-Tv4 enhances growth promoter and plant defense- related enzymes of mungbean (Vigna radiata) against soil-borne pathogen Rhizoctonia solani
}

\author{
ALFI INAYATI ${ }^{1,2, \boldsymbol{v}}$, LILIEK SULISTYOWATI ${ }^{1}$, LUQMAN QURATA AINI ${ }^{1}$, ERIYANTO YUSNAWAN $^{2}$ \\ ${ }^{1}$ Department of Plant Pest and Disease, Faculty of Agriculture, Universitas Brawijaya. Jl. Veteran, Malang 65145, East Java, Indonesia. \\ Tel.: +62-341-551665, 565845, Fax.: +62-341-560011, `email: alfiinayati2@gmail.com \\ ${ }^{2}$ Indonesian Legumes and Tuber Crops Research Institute, Indonesian Agency for Agricultural Research and Development. J1. Raya Kendalpayak Km 8 , \\ Malang 65162, East Java, Indonesia
}

Manuscript received: 29 January 2020. Revision accepted: 10 May 2020.

\begin{abstract}
Inayati A, Sulistyowati L, Aini LQ, Yusnawan E. 2020. Trichoderma virens-Tv4 enhances growth promoter and plant defenserelated enzymes of mungbean (Vigna radiata) against soil-borne pathogen Rhizoctonia solani. Biodiversitas 21: $2410-2419$. Trichoderma virens has been studied for its ability to control various soil-borne pathogens as well as to induce plant resistance. The ability of $T$. virens control $R$. solani and its capability to induce resistance was evaluated in two different genotypes of mungbean (Vigna radiata (L.) R. Wilczek). Plant growth-promoting capability and production of plant defense-related enzymes during plant-pathogenTrichoderma interaction were investigated. Pathogen infection caused the morphological and biochemical changes as well as increased plant defense enzymes activity such as peroxidase, polyphenol oxidase, PAL, phenolics, and flavonoid compared to control uninoculated plants. T. virens improved mungbean seedling growth in terms of increased total biomass, root weight, and root length as well as improved chlorophyll content and IAA-synthase from leaves and roots. T. virens treatment alone or in the presence of pathogeninduced mungbean defense-related enzymes indicated by the increasing of PO and PPO activity, and higher accumulation of total phenolic and flavonoid content. Although most of plant induced resistance parameters showed low and non-significant in direct singlefactor comparison, Pearson's correlation showed there was a positive correlation between plant growth promoter compounds (IAA and chlorophyll) with plant defense-related enzymes (total phenol, and flavonoid content). T. virens treatment can induce systemic defense response of mungbean seedling directly by increasing the activity of some defense-related enzymes, and indirectly by improving plant health, and promoting plant growth. In conclusion, T. virens-Tv4 has potential to be developed as bio-control agents to control $R$. solani as well as to induce mungbean resistance.
\end{abstract}

Keywords: Growth promotor, induced resistance, mungbean, plant defense-related enzymes, Trichoderma virens

\section{INTRODUCTION}

Trichoderma species have been studied for decades as effective bio-control agents against many pathogens through various modes of action (Howell 2003; Harman 2011). Initially, most studies of Trichoderma spp. were focused on the ability of these fungi to directly suppress the growth of pathogens with specific mechanisms such as mycoparasitism, production of antibiotics, and competitions for space and nutrition in the rhizosphere (Howell et al. 1993; Shakeri and Foster 2007; Wu et al. 2017). Recently, most of the research is now concentrated on the mechanisms involved in Trichoderma-plantpathogen interaction to further explore the potential of Trichoderma as multifunctional bio-control agent (Harman 2011; Singh et al. 2014). Numerous studies indicate the ability of Trichoderma spp. to reprogram plant genes expression that change plant proteome and metabolome which alleviate physiological and biochemical change, and improve plant resistance to biotic and abiotic stresses (Woo et al. 2006; Mukherjee et al. 2012; Castillejo et al. 2015; Mazzei et al. 2016).

In plant-pathogen-Trichoderma interaction, Trichoderma is able to activate plant defense mechanisms mostly for induced systemic resistance (ISR), rarely systemic acquired resistance (SAR) (Hermosa et al. 2012; Martínez-Medina et al. 2014). The latest study proposed mixed ISR/SAR type of resistance called Trichoderma-induced systemic resistance (TISR) (Martínez-Medina et al. 2013; MartínezMedina et al. 2014; Pieterse et al. 2014). However, the mechanism of defense responses induction and the type of resistance induced in plants by Trichoderma still remain unclear (Harman et al. 2012).

Trichoderma colonization can trigger plant defense systems not only restricted to the root, but could also be marked in above-ground plant tissues and increasing the spectrum of plant resistance to various pathogens (Martínez-Medina et al. 2013; Shoresh and Harman2010). Shoresh and Harman (2008) showed that roots colonization with $T$. harzianum T22 induced systemic resistance of maize seedling against soil-borne and foliar diseases as well as promotes overall plant growth. Another study showed that the challenge of cucumber seedlings by pathogen Pseudomonas syringae pv. lachrymans and T.asperellum (T203) increase the levels of plant defenserelated enzymes such as peroxidases, chitinases, and $\beta-1,3-$ glucanases (Shoresh et al. 2005). Other enzymes related to plant defense such as polyphenol oxidase (PPO), 
phenylalanine ammonia-lyase (PAL) that involved in synthesis of phytoalexin and phenolic compounds also reported increase in legume treated by T.viride (Surekha et al. 2014). According to the reported study, it is suggested that the induction of plant resistance in different hosts may require different signaling, and the induction was represented in different manner (Martínez-Medina et al. 2013).

Trichoderma virens as well as other Trichoderma spp, can induce both localized and systemic resistance in various plant species and pathogens (Howell 2006; Contreras-Cornejo et al. 2009; Angel et al. 2016; Małolepsza et al. 2017). Latest study from Dubey et al. (2018) showed that there were up-regulated expression of some defense-related genes and catalase in response to the presence of $T$. virens and $R$. solani. However, there were still many gaps in the physiological, biochemical, and molecular changes related to $T$. virens-mungbean induced defense responses against soil-borne pathogen $R$. solani. More studies also needed to understand Trichoderma-ISR on mungbean-pathogen system which improves efficient formulation for wide application in agriculture. Our previous study showed that $T$. virens-Tv4 strain has relatively high mycoparasitic capacity and able to produce plant hormone IAA and phosphate solubilizer enzyme in vitro (data not shown). T. virens also increase total phenol and flavonoid content on soybean seedling (Yusnawan et al. 2019). However, the effectiveness of $T$. virens strains in inducing mungbean resistance was not previously tested. In this study, we analyze the ability of $T$. virens-Tv4 to induced mungbean resistance against soil-borne pathogen $R$. solani as well as its ability to promote plant growth and development. Trichoderma spp. has been reported to increase plant growth and development through increased nutrient solubility and availability, and nutrient uptake capacity (Zhang et al. 2016). In Arabidopsis, Trichoderma spp. also found induced growth of lateral roots through the production of auxin (Contreras-Cornejo et al. 2009). Changes in enzymes related to plant defense such as phenylalanine ammonia-lyase (PAL), Tyrosine ammonialyase (TAL) activity, peroxidase, polyphenol oxidase, and total phenolic were evaluated during plant-pathogenTrichoderma interaction. We also observe the accumulation and synthesis of phytohormone (IAAsynthase and IAA-oxidase) and chlorophyll content in the presence of $T$. virens, $R$. solani or both $T$. virens and $R$. solani compare to uninoculated control plants. Principal component analysis (PCA) was used to explain the influence of the enzymes alteration in plants on the induction of plant resistance by $T$. virens.

\section{MATERIALS AND METHODS}

\section{Plant and fungal material}

Trichoderma virens strain Tv4 and $R$. solani isolates were obtained from Mycology Laboratory of Indonesian Legumes and Tuber Crops Research Institute, Malang, Indonesia. $T$. virens strain was cultured in PDA plates for 5 days before use, while $R$. solani was cultured on rice husk according to method proposed by Shrestha et al. (2016) with modification. Briefly, $1000 \mathrm{~g}$ of the mixture of rice husk and brand (4: $1 \mathrm{w} / \mathrm{w})$ were moisturized with approximately $200 \mathrm{~mL}$ of water containing $20 \mathrm{~g} / \mathrm{L}$ of glucose. The mixture was then sterilized at $121{ }^{\circ} \mathrm{C}$ for 20 min. The sterilized husk mixture medium was inoculated with three to five plugs (diameter $0.5 \mathrm{~cm}$ ) of $R$. solani mycelia from 7 day-old PDA culture and incubated at room temperature for 7 days. Two different genotypes of mungbean, Sampeong, and Vima-3 which have different resistance levels based on previous study were used in this study.

\section{Greenhouse experiment}

Seeds of mungbean were sterilized with $0.5 \% \mathrm{NaOCl}$ and rinsed twice with sterile distilled water. Trichoderma suspension was prepared according to Yusnawan et al. (2019). In general, conidia of T. virens were harvested from the 7 days-old culture, and then sterile distilled water was added to adjust the spore concentration approximately $10^{6}$ $\mathrm{CFU} / \mathrm{mL}$. The seeds were then dipped into the suspension for 30 minutes to trigger initial imbibition of the seeds before planting. For control treatment, mungbean seeds were dipped in sterile water. Four different treatments were tested: (i) R: plants were non-treated with $T$. virens and challenged with $R$. solani, (ii) TR: plants treated with $T$. virens and challenged with $R$. solani, (iii) T: plants were treated only with $T$. virens and (iv) C: control plants, nontreated with $T$. virens, and non-challenged with $R$. solani, For $R$. solani challenged treatment, $R$. solani from rice husk (10 g/pot) was spread uniformly to the sterile soil 2 days before planted. All plants for sample were taken from 21 days old seedling.

\section{Determination of plant enzymes related to plant growth promoter and plant defense \\ IAA-synthase}

IAA-synthase was determined as per the method given by Phelps and Sequeira (1967) with modification. Enzyme was prepared by finely ground $0.5 \mathrm{~g}$ of plant tissue (leaves and roots) then add $5 \mathrm{~mL}$ of $0.05 \mathrm{M}$ phosphate buffer saline, $\mathrm{pH}$ 5.8. The reaction mixture contained $500 \mu \mathrm{L}$ extract, $50 \mu \mathrm{L} \mathrm{MnCl}_{2}(0.2 \mathrm{mM}), 10 \mu \mathrm{L} \mathrm{MgSO}_{4}(0.01 \mathrm{M})$, $1500 \mu \mathrm{L}$ PBS, and $500 \mu \mathrm{L}$ L-tryptophan $(125 \mathrm{mg} / 50 \mathrm{~mL})$. The mixture was incubated at $37{ }^{\circ} \mathrm{C}$ for $30 \mathrm{~min}$. The reaction was started by added $2.5 \mathrm{~mL}$ Salkowski reagent and incubated at room temperature for 15 minutes to developed stable pink color and the absorbance was read at $530 \mathrm{~nm}$. The enzyme activity was expressed as $\mu \mathrm{g}$ IAA produced per minute per gram fresh weight of tissue.

\section{Chlorophyll content}

Chlorophyll content was determined according to Lichtenthaler and Buschmann (2001). $0.5 \mathrm{~g}$ leaves from 21 days old mungbean seedling were grounded with $5 \mathrm{~mL}$ methanol $90 \% \quad(\mathrm{v} / \mathrm{v})$. The chlorophyll and carotenoid content was quantified by spectroscopic absorbance at three different wave lengths, $470 \mathrm{~nm}, 652.4 \mathrm{~nm}$, and 665.2 $\mathrm{nm}$. Concentration of chlorophyll and carotenoids were calculated following equation given:

Ch-a $(\mu \mathrm{g} / \mathrm{mL})=16.82 \mathrm{~A}_{665.2}-9.16 \mathrm{~A}_{652.4}$

Ch-b $(\mu \mathrm{g} / \mathrm{mL})=34.09 \mathrm{~A}_{652.4}-16.54 \mathrm{~A}_{665.2}$

$\mathrm{Ch}(\mathrm{x}+\mathrm{c})(\mu \mathrm{g} / \mathrm{mL})=\left(1000 \mathrm{~A}_{470}-1.91 \mathrm{Ch}-\mathrm{a}-95.15 \mathrm{Ch}-\mathrm{b}\right) / 225$ 
Peroxidase activity ( $P O)$ and polyphenol oxidase (PPO)

PO activity was determined following the method Ata et al. (2008) with modification. Samples of was ground in 5 $\mathrm{mL}$ of sodium phosphate buffer $(\mathrm{pH}$ 6.5) centrifuged for 10 $\min$ at $12000 \mathrm{rpm}, 4^{\circ} \mathrm{C}$. The reaction mixture consisted of $2.9 \mathrm{~mL}$ of $100 \mathrm{mM}$ sodium phosphate buffer $(\mathrm{pH} 6.5)$ containing $0.25 \%$ (v/v) catechol and $100 \mathrm{mM} \mathrm{H}_{2} \mathrm{O}_{2}$.

PPO activity was determined according to the method described by Malik and Singh (1980). The reaction mixture contained $3.0 \mathrm{~mL}$ buffered catechol solution $(0.01 \mathrm{~m})$, freshly prepared in $0.1 \mathrm{~mL}$ phosphate buffer $(\mathrm{pH} \mathrm{6.5)}$. The reaction was started by adding $100 \mu$ l of the crude enzyme extract. Changes in the absorbance at $495 \mathrm{~nm}$ were recorded every 30-sec intervals for 1 hour. Enzyme activity was expressed as increase in absorbance $\min ^{-1} \mathrm{~g}^{-1}$ fresh weight.

\section{Phenylalanine ammonia-lyase (PAL)}

PAL and TAL activity was assayed according to methods proposed by Dogbo et al. (2012) with modification. Crude enzyme for PAL assay was prepared by finely ground of $0.5 \mathrm{~g}$ plant tissue (leaves or roots) with $5 \mathrm{~mL}$ $0.1 \mathrm{M}$ borate buffer, $\mathrm{pH}$ 8.8. The solution then sonicated for 10 minutes then centrifuged at $10000 \mathrm{rpm}, 4^{\circ} \mathrm{C}$ for 10 minutes. PAL reaction mixture contained $300 \mu \mathrm{L}$ extract, $300 \mu \mathrm{M}$ sodium borate, $30 \mu \mathrm{M}$ L-phenylalanine, and the mixture than adjusted to $3.5 \mathrm{~mL}$ with distilled water. Incubation was done at $30^{\circ} \mathrm{C}$ for $60 \mathrm{~min}$ and the absorbance at $290 \mathrm{~nm}$. The enzyme activity was expressed as millimoles cinnamic acids produced per minute per gram fresh weight of tissue.

\section{Total phenolic and flavonoid content}

Phenolic and flavonoid extract was prepared by dissolving $0.5 \mathrm{~g}$ finely ground leaves in $5 \mathrm{~mL} 80 \%$ methanol. Phenolic content was estimated using FolinCiocalteu's reagent according to Yusnawan (2016) which expressed as Gallic acid equivalents per gram of sample (mg GAE/g sample). Total flavonoid content was measured with $\mathrm{AlCl}_{3}$ (Heimler et al. 2005) which expressed as catechin equivalents per gram of sample ( $\mathrm{mg} \mathrm{CE} / \mathrm{g}$ sample) based on dry basis using the calibration curve of the catechin.

\section{Data analysis}

Analyses of variance (ANOVA) from data of plant growth and resistance parameters and enzymes assays were calculated using Microsoft Excel software. Least Significant Difference (LSD) was performed on 0.05 confidence level. The robust analysis of principal component (PCA) was calculated using R-studio statistical environment $\mathrm{R}$ version 3.5.3 (Team 2015).

\section{RESULTS AND DISCUSSION}

\section{Mungbean growth and resistance against $R$. solani infection and Trichoderma virens treatment}

Plant-pathogen-Trichoderma interaction triggers positive and negative effects on plants. In mungbean- $R$. solani-T. virens interaction, there was change in plant defense reactions which directly and indirectly influence the response of mungbean seedling to pathogen infection. $R$. solani infection causes the seeds to rot and abnormality, root rot, and death because of damping-off (Figure 1). Some seedling infected by $R$. solani on their hypocotyls showed the ability to recover and continued to grow by production of new green tissue (Figure 1.D). This indicated the resistant expression of mungbean genotype that could overcome $R$. solani infection. Bengyella et al. (2015) reported that a key feature to plant recovery from pathogen attack is the degree of the host's initial basal immunity response. In plant recovery process, pathogen attack trigger plant response to by-pass the development of severe symptom which leads to partial or complete recovery. The percentage of plant recovery showed significant correlation with the level of resistance (Bengyella et al. 2015).

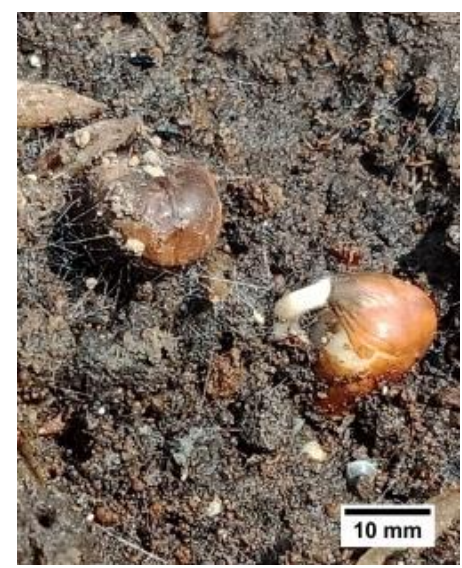

A

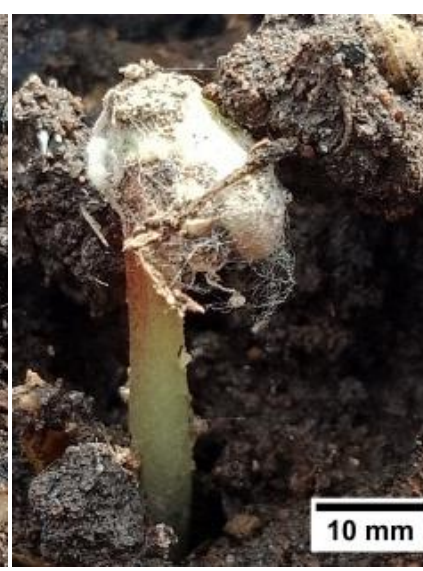

B

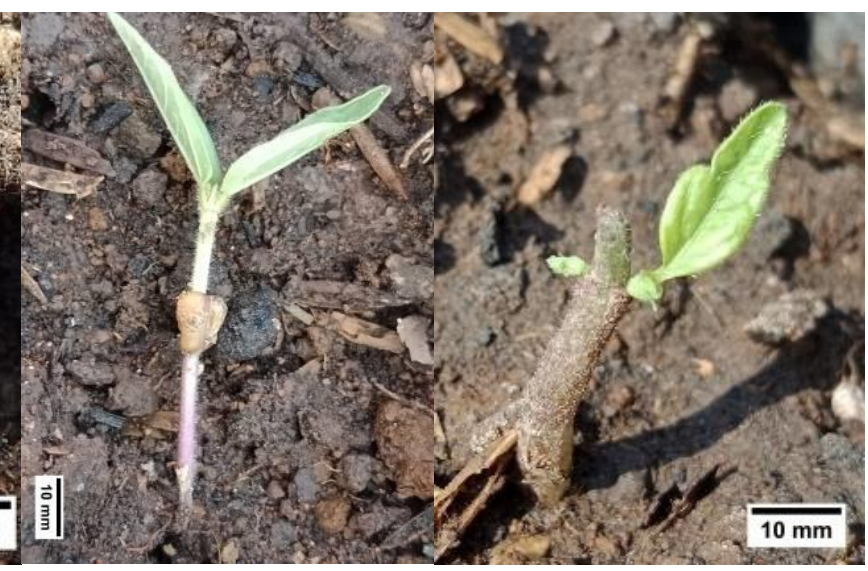

C
D

Figure 1. Rhizoctonia solani infection symptoms; A. Seed rot, B. Hypocotil rot, C. Damping-off, D. Seedling abnormality caused by $R$. solani infection 


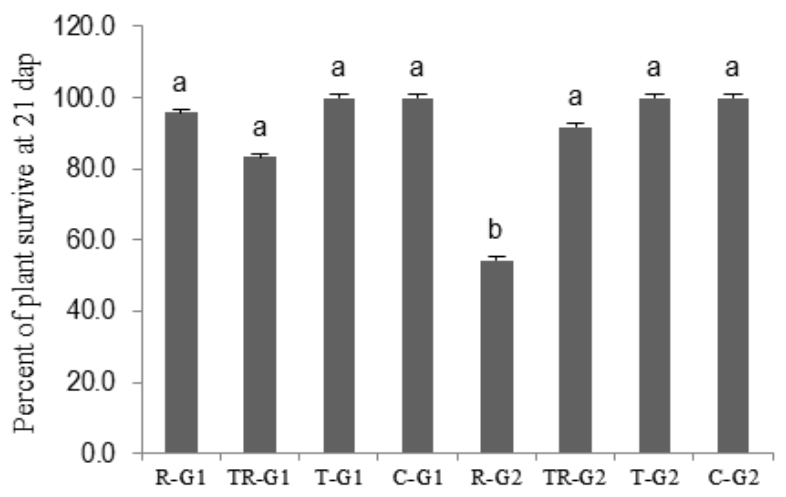

A
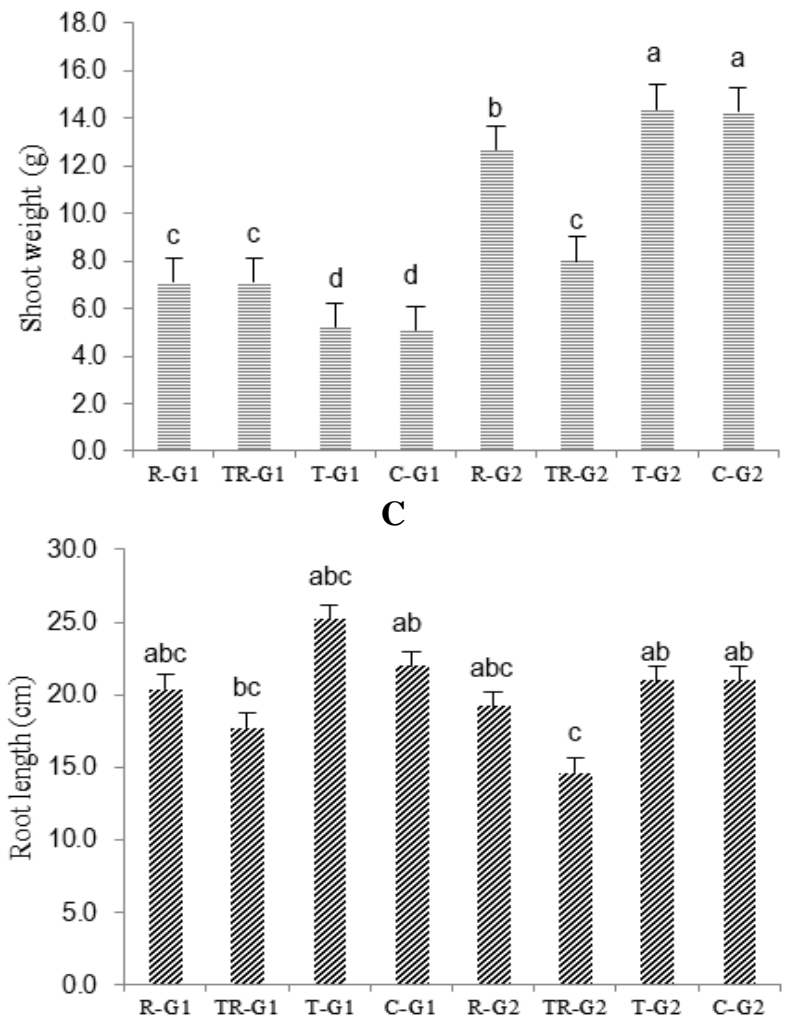

$\mathbf{E}$

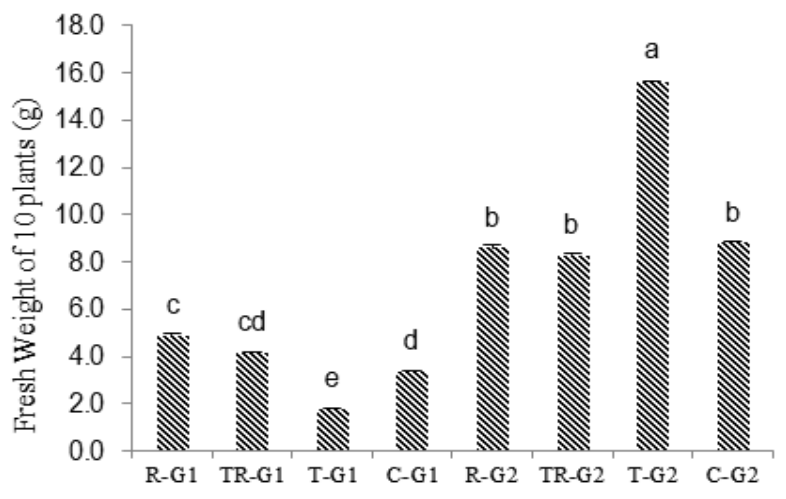

B
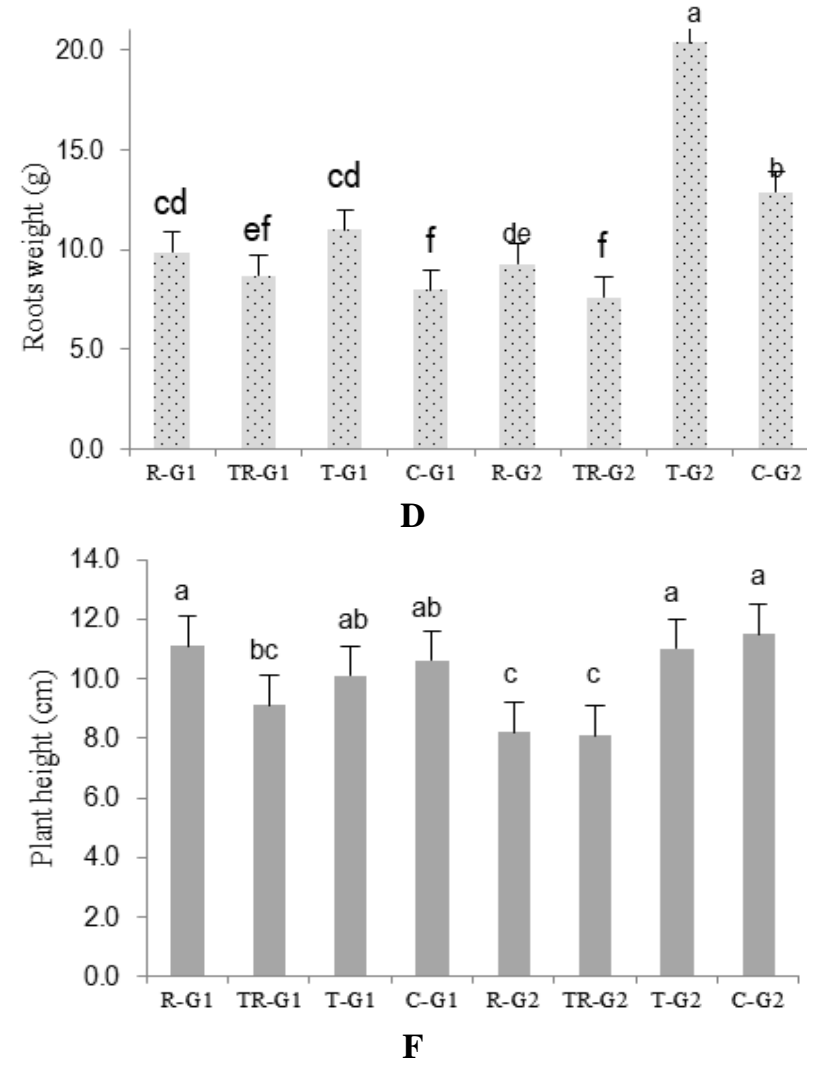

Figure 2. A. Percent survive plants at 21 dap, B. Total fresh weight of 10 plants, C. Fresh weight of shoot, D. Fresh weight of roots, E. Root length, F. Plant height

There was no significant difference between plants survive in control treatment with plant treated by $T$. virens in both genotypes at 21 days after planting (dap) as well as the resistance to $R$. solani infection showed by two genotypes tested (Figure 2). Although in vitro assay showed that Tv4 strain has a relatively high ability to suppress $R$. solani, but when interacting with plants, the mycoparasitic ability of $T$. virens is not directly and fully exposed. When plant challenged with pathogen, defense response is not activated directly, but it needs time to accelerated attack upon by pathogen or other pests (Van der Ent et al. 2009).

Trichoderma virens treatment increased the total biomass of G1 seedling as compared to control, however, G2 presented different responses which only seed treatment with $T$. virens alone increase the fresh weight. Seeds treated with $T$. virens also affect the root weight and length indicated that $T$. virens promotes the root growth, however, $T$. virens treatment showed no effect on the shoot growth. Trichoderma spp. colonization has been reported to improve nutrient uptake and availability as well as the allocation of biomass in some plants such as melon (Martínez-Medina et al. 2011) and tomato (Tucci et al. 2011). Since improved in plant nutrition is considered as one of the mechanisms responsible for plant protection against pathogen, root colonization by Trichoderma also reported could enhance not only crop yield but also resistance to biotic and abiotic stresses (Harman et al. 2004; Whipps and Lumsden2001). Our study showed there was no significant increase in plant resistance which 
represented by number of plant survive with the increase in plant growth parameters such as plant biomass and root growth. It can be suggested that there were other mechanisms involved in the mungbean resistance against $R$. solani. The study conducted by Martínez-Medina et al. (2013) also showed that systemic protection of tomato treated by T.harzianum was not related to nutrition improvement or growth promotion.

\section{Determination of plant growth promoter induced in mungbean- $R$. solani-T. virens interaction}

IAA-synthase measurement

Plant growth promotion in mungbean seedling represented by the increase in IAA synthase from both roots and leaves of $\mathrm{G} 2$ seedling treated with $T$. virens as compared to control treatment (Figure 3). However, G1 showed slightly different responses, only seedling challenged with pathogen and $T$. virens displayed significant increase in IAA synthase from the leaves. The highest IAA-synthase was showed in G1 roots infected by $R$. solani which increase up to 9 fold higher as compare to control plant. In contrast, pathogen infection and $T$. virens treatment decrease the IAA in G2. The correlation between IAA synthase and the growth parameters (root length, plant height, and plant biomass) was not clear, indicated that the capability of $T$. virens synthesizing IAA not directly correlates with promotion of the plant growth. ContrerasCornejo et al. (2009) reported that Trichoderma spp. could induce plant growth by fungal auxin-dependent mechanism even the correlation between them is less convincing. Our study showed, there was negative correlation between IAAsynthase in leaves with root length and plant height, however, positive correlation showed between IAAsynthase in roots with the total biomass, and the plant height. Altogether our results suggest that the mechanisms and molecules involved in plant growth promotion of mungbean seedling by $T$. virens are multivariable and also affected by the environmental conditions.

\section{Chlorophyll content measurement}

Change in chlorophyll content from mungbean infected by $R$. solani and treated by $T$. virens was varied among genotypes (Figure 4). There was increase in chlorophyll content in treated G1 plants compared to untreated plants, indicating the growth-promoting ability of $T$. virens. However, pathogen infection cause chlorophyll a, b, and carotenoid decrease in G2 seedling indicating that there was genotype-specific response in chlorophyll content changes. Chlorophyll content is very important in photosynthesis, especially chlorophyll a and b. The decrease in plant chlorophyll content affects photosynthesis and attributed to decrease yield (Durairaj et al. 2018). Plant chlorophyll content also indicates the health of plants and strongly related to its biophysical conditions (Moharana and Dutta 2016). Photosynthesis play critical process in plant physiology, and its regulation play an important role in plant defense (Pérez-Bueno et al. 2019), as a result, the changes in energy source and signaling on photosynthesis process affect plant regulation pathways including defense response to biotic and abiotic challenges (Kangasjärvi et al. 2012). The changes in plant chlorophyll content could be part of mungbean defense mechanisms to limit the nutrient availability to the pathogen.

\section{Determination of plant defense-related enzymes induced in mungbean- $R$. solani-T. virens interaction}

Induction of plant defense mechanism was evaluated by determination of plant defense-related enzymes such as peroxidase (PO), polyphenol oxidase (PPO), phenylalanine ammonia-lyase (PAL), total phenols, and flavonoid content. $T$. virens treatment and pathogen infection also trigger plant defense-related enzymes.
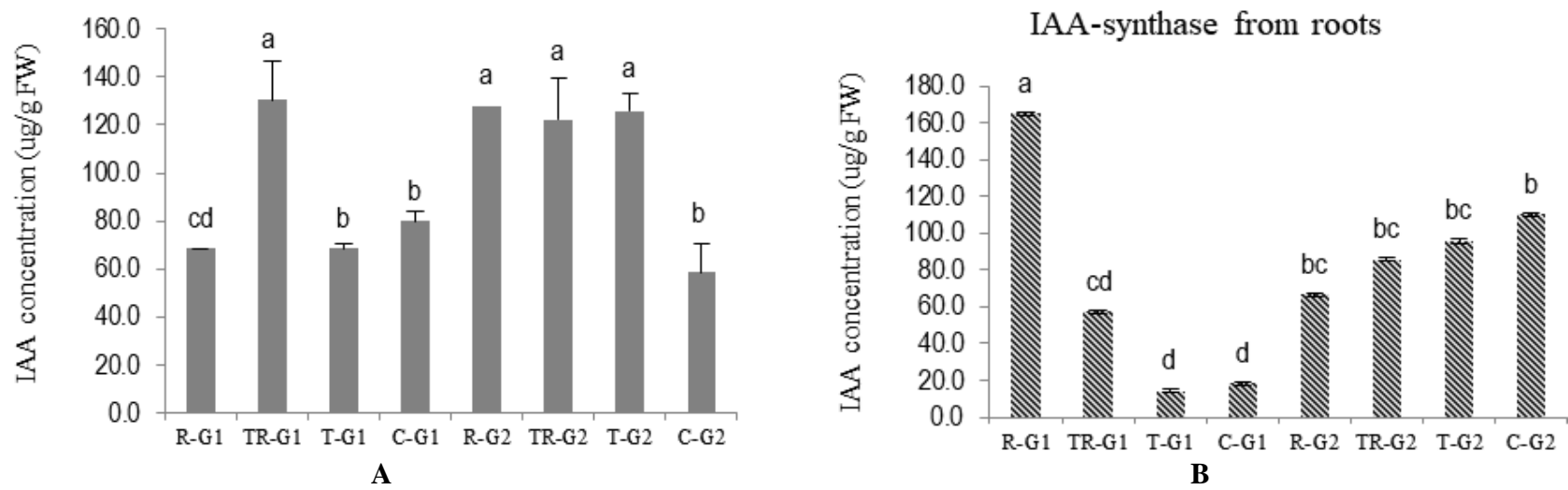

Figure 3. IAA concentration on: A. leaves, B. roots of mungbean seedling. R; plant infected by Rhizoctonia solani, TR; plant infected by $R$. solani and treated by Trichoderma virens, T; plant treated by T. virens, and C; control 


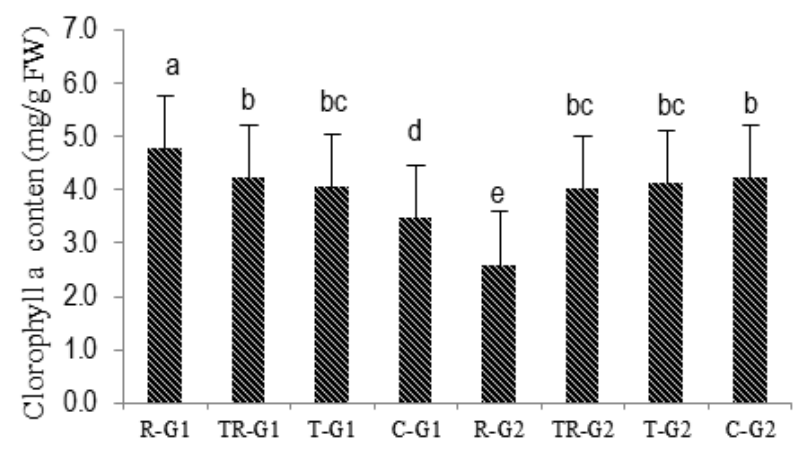

A

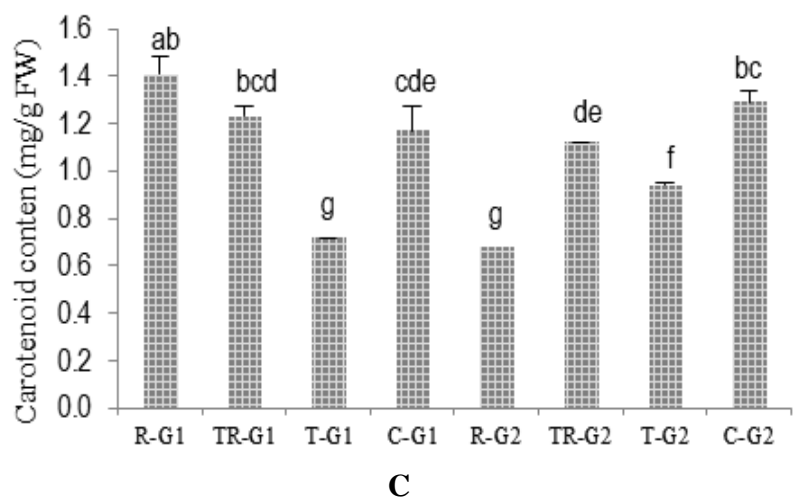

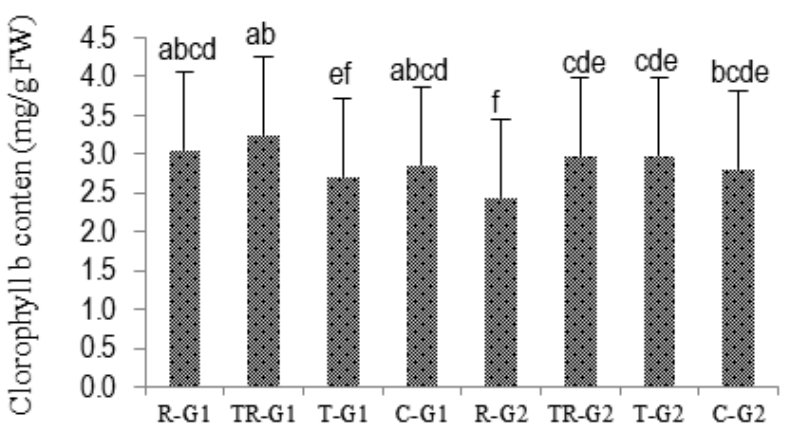

B

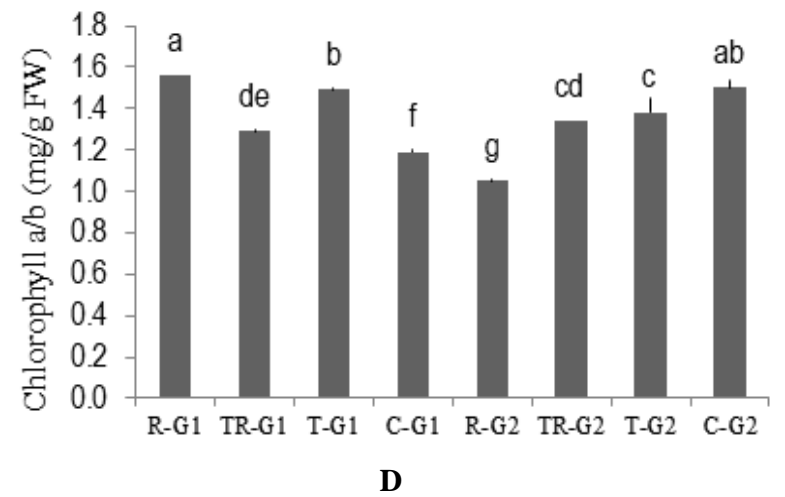

Figure 4. Chlorophyll contents of mungbean plants. A. Chlorophyll a, B. Chlorophyll b, C. Carotenoid, D. Comparison of chlorophyll a/b
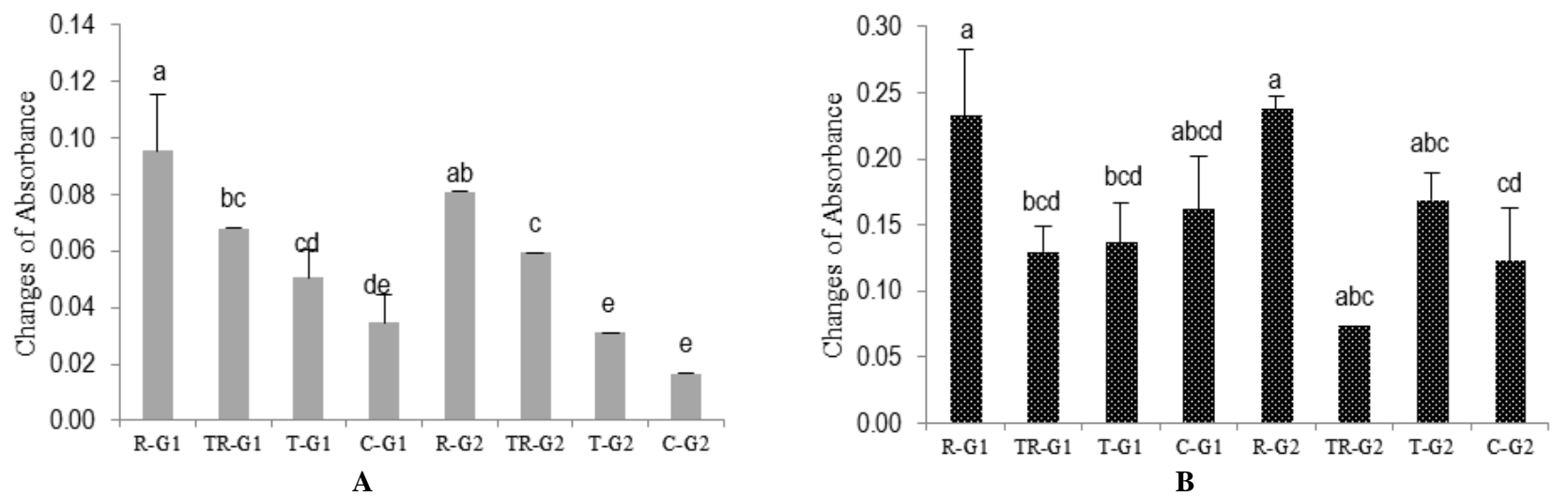

Figure 5. Differences in peroxidase (PO) and Polyphenol oxidase (PPO) activity in mungbean seedling treated by Trichoderma virens; A. Peroxidase (PO) activity in mungbean roots, B. Polyphenol oxidase (PPO) activity in mungbean roots

\section{Peroxidase (PO) and polyphenol oxidase (PPO)}

Peroxidase activity was higher on mungbean seedling when interacted with microorganisms both pathogenic and non-pathogenic. Pathogen infection increases the peroxidase activity as well as $T$. virens treatment (Figure 5.A). There was significant increase in PO activity due to pathogen infection; however, seed treatment with $T$. virens alone didn't show significant effect on PO activity. This fact showed that pathogen triggers stronger mungbean defense signals than $T$. virens. Peroxidase and peroxidase activity has been reported to play important role to initiate plant defense response against pathogens through establishment of structural barriers (lignin accumulation) or generation of highly toxic environments by massively producing ROS, and synthesis of phenolic compounds (Mahanta 2012; Thakker et al. 2012; Adhilakshmi et al. 2014). PO also actively involved in the self-regulation associated with growth regulation including respiration and photosynthesis (Kavitha and Umesha 2008).

Pathogen infection also increases polyphenol oxidase, however $T$. virens pretreatment on mungbean seed did not show adequate evidence whether $T$. virens treatment plays significant role in increasing PPO activity of mungbean seedling. There was significantly different in PPO changes in plant infected by $R$. solani in both genotypes, but only G2 treated with $T$. virens showed increase in PPO activity while others were decreased (Figure 5.B). PPO has been suggested to play important role in disease resistance due 
to its ability to catalyze oxidation of phenolic compounds into quinones and lignin biosynthesis (Constabel and Barbehenn 2008; Kavitha and Umesha 2008). However, another study showed that PPO activity not directly correlated in plant defense response (Hoagland 1990). Pearson's correlation showed, there was negative correlation between PPO activity and number of surviving plant, and has no correlation with total phenol indicate PPO activity not directly involved in induced resistance of mungbean against $R$. solani.

\section{Phenylalanine ammonia-lyase (PAL)}

Phenylalanine ammonia-lyase (PAL) has been reported as key enzymes involved in plant defense mechanisms because it synthesizes various phenolic compounds, including flavonoids, hydrocinnamates (Hoagland, 1990), and enters different biosynthetic pathways leading to lignin synthesis (Kavitha and Umesha 2008; Solekha et al. 2019). Our study showed, there was different trend in PAL activity from leaves and roots of mungbean seedling and there also variation of PAL activity among treatment (Figure 6). PAL activity in leaves was relatively higher than in roots. Only G1 seedling treated with $T$. virens showed increase in PAL activity in leaves, while other treatments showed no effect or tend to decrease compared to untreated plants (Figure 6.A). In roots, pathogen infection increase PAL activity of G1 genotype, however, there was no difference in PAL activity in G2 roots (Figure 6.B). Different expression of PAL has been reported in many studies, for example in wheat, the activity of PAL was influenced by deoxynivalenol (DON, Fusarium mycotoxin), as a result, downregulation of PAL in susceptible variety (Duba et al. 2019).). Although it is difficult to explain the inhibitory effect of Trichoderma on PAL activity in mungbean-pathogen-Trichoderma interaction, a possible explanation was biosynthesis of PAL from L-phenylalanine may occur in mungbean system may follow more than one route and PAL reaction is not the only one of defense response pathways.

\section{Total phenolic and flavonoid content}

Phenolics are one of the largest and most diverse groups of plant active substances involved in the plant growth regulation, and also plays important role in defense responses during pathogen infection and abiotic stress (Kubalt 2016; Mandal et al. 2010). Pathogen infection caused an increase in total phenolic content in G1, however, it's decreased in G2 genotype compared to noninfected plants (Figure 7.A). Seed treatment with $T$. virens has slightly increased the accumulation of total phenol, however, there was no significant increase in phenolic content triggered by $T$. virens when applied in seed without pathogen treatment. This indicated the presence of pathogen was important to trigger $T$. virens capacity to induce phenols accumulation and activate the plant defense mechanism. Phenolics are synthesized when plants recognize potential pathogens (Bhattacharya et al. 2010; Kubalt 2016). However, there are other factors which influence phenol accumulation such as plant genetics or species (Bhattacharya et al. 2010), nutrient status, and environmental factors such as temperature and light (Løvdal et al. 2010) suggest that relationship between elicitor activity and specificity in a plant-microbe interaction is highly complex.

Flavanoids belong to polyphenols compounds play multifunctional roles and involved in plant-microbe interaction (Bekkara et al. 1998). Generally, pathogen infection and the $T$. virens treatment increase the flavonoid content of mungbean seedling except for G2 seedling which showed $R$. solani infection caused a decrease in flavonoid content (Figure 7.B). Most elevated accumulation of flavonoid compounds was showed in G1 genotype infected by $R$. solani while G2 genotype showed the opposite result pointed out the specific response of mungbean genotype to $R$. solani infection. Treutter, (2005) explained that plant defense-related flavonoids can be divided into "performed" and "induced" compounds. Trichoderma spp. application and pathogen infection have been reported could induce the accumulation of flavonoid compounds, however, sometimes it is difficult to notice the accumulation of flavonoids in plants induced by external factors or expression of their constitutive flavonoids. There was no difference in constitutive level of flavonoids content of G1 and G2 pointed out the increase/decreased of flavonoid content in treated plants was influenced by the treatment.
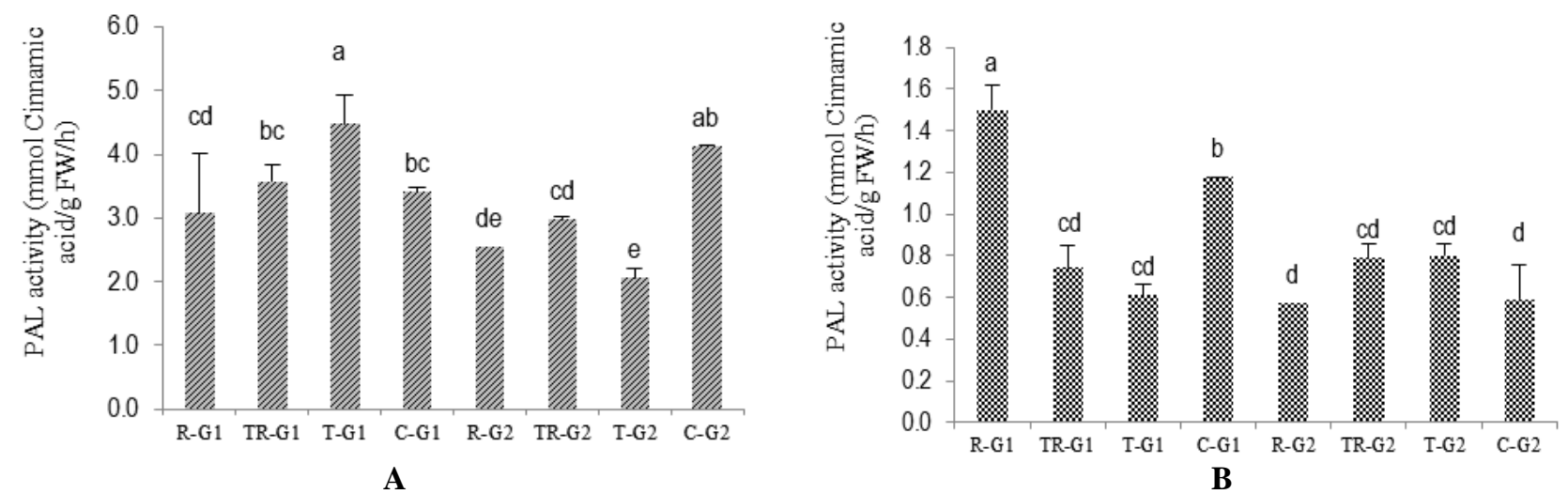

Figure 6. Changes in PAL activity on mungbean seedling in different part of plant; A. PAL activities in leaves, B. PAL activity in roots 


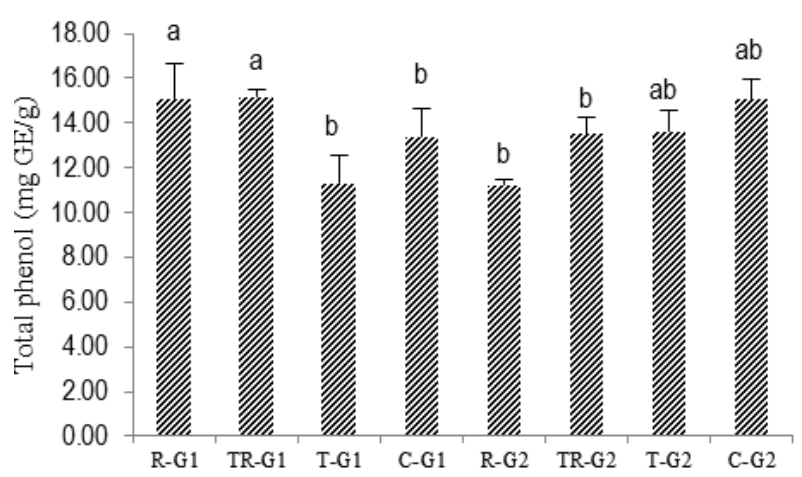

A

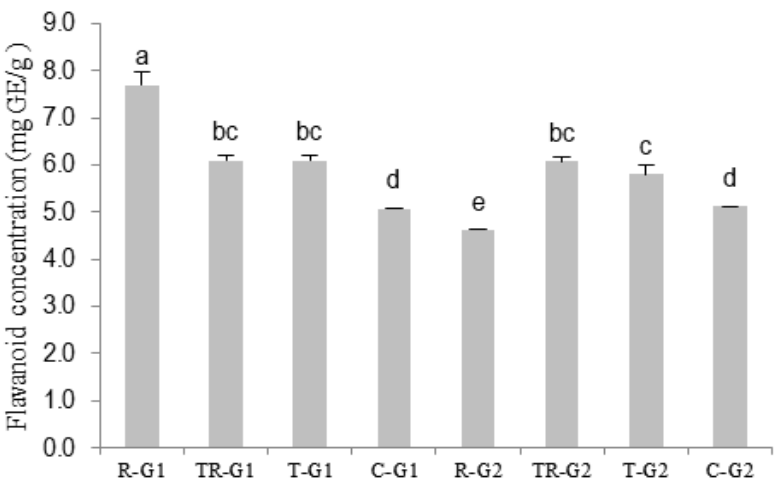

B

Figure 7. Changes in total phenolic and flavonoid content in mungbean seedling infected by Rhizoctonia solani and Trichoderma virens seed treatment: A. Total phenol in mungbean roots, B. Flavonoid concentration in mungbean roots

\section{Correlation among enzymes related to plant growth and plant defense}

In general, most of plant induced resistance parameters showed low and non-significant in direct single-factor comparison. Pearson's correlation was determinate among plant enzymes and resistant parameter to help interpretation of the data variability presented in Table 1. The result showed, there was positive correlation between chlorophyll content with the plant survival, indicating that plant chlorophyll involved in plant defense mechanism of mungbean against $R$. solani. Another plant growth promoter that played important roles was IAA-synthase in roots. IAA-synthase in roots showed positive correlation with chlorophyll-a, total phenol, and flavonoid content. This result indicated that auxin production in the roots can induce the plant defense enzymes in mungbean defense system. Peroxidase and polyphenol oxidase also showed positive correlation with flavonoid content which implied the contribution of those two enzymes in induced mungbean defense response.

The principal component analysis (PCA) also conducted to all enzymes and growth parameters data. PCA analysis showed that two principal components (PC1 and PC2) explaining $62.9 \%$ of the overall variance (Figure 8 ). The PC1 plot showed the contribution of $34.7 \%$ of the explained variance was positively related to the chlorophyll content, total phenolic content, PAL, and IAA-synthase in roots. Whereas, PC2 loading plot that contributed to $28.3 \%$ of the explained variance. In PC2 plot, the separation occurred due to peroxidase activity and root length. Based on the genotype grouping, the variables on the plant infected by $R$. solani (R-G1, R-G2) were completely separated from $T$. virens treatment (T-G1, T-G2), indicated that treatment greatly influences the plant response. Though control uninoculated plants grouped together with the plants treated with $T$. virens and pathogen.

Table1. Pearson's correlation matrix among plant defense-related and growth promoter enzymes with mungbean resistance to Rhizoctonia solani

\begin{tabular}{|c|c|c|c|c|c|c|c|c|c|c|c|c|}
\hline & Surv & FW & RL & IAA-R & IAA-L & Chl-a & Chl-b & PO & PPO & PAL-R & Phe & Flav \\
\hline Surv & 1 & 0.05 & 0.37 & 0.06 & -0.58 & $\mathbf{0 . 7 3}$ & 0.48 & -0.46 & -0.53 & 0.33 & 0.41 & -0.46 \\
\hline FW & & 1 & 0.12 & 0.36 & 0.16 & 0.03 & -0.12 & -0.42 & 0.14 & -0.34 & 0.06 & 0.02 \\
\hline RL & & & 1 & -0.32 & -0.64 & 0.03 & -0.34 & 0.31 & -0.33 & 0.02 & -0.33 & -0.50 \\
\hline IAA-R & & & & 1 & -0.11 & 0.52 & 0.29 & 0.42 & 0.37 & 0.27 & 0.60 & 0.72 \\
\hline IAA-L & & & & & 1 & -0.39 & 0.13 & -0.03 & 0.22 & -0.31 & -0.15 & 0.29 \\
\hline Chl-a & & & & & & 1 & 0.75 & -0.30 & 0.04 & 0.41 & 0.71 & 0.05 \\
\hline Chl-b & & & & & & & 1 & -0.38 & 0.07 & 0.42 & 0.80 & 0.21 \\
\hline PO & & & & & & & & 1 & 0.50 & 0.36 & -0.22 & 0.58 \\
\hline PPO & & & & & & & & & 1 & 0.37 & -0.01 & 0.72 \\
\hline PAL-R & & & & & & & & & & 1 & 0.43 & 0.51 \\
\hline Phe & & & & & & & & & & & 1 & 0.39 \\
\hline Flav & & & & & & & & & & & & 1 \\
\hline
\end{tabular}

Note: Surv number of plant survive, FW total fresh weight, RL roots length, IAA-R IAA-synthase from roots, Chl-a chlorophyll a, Chl-b chlorophyll b, PO peroxidase, PPO polyphenol oxidase, PAL phenylalanine ammonia-lyase, Phe Phenolic content, and Flav flavonoid content 
PCA of plant defense-related enzymes

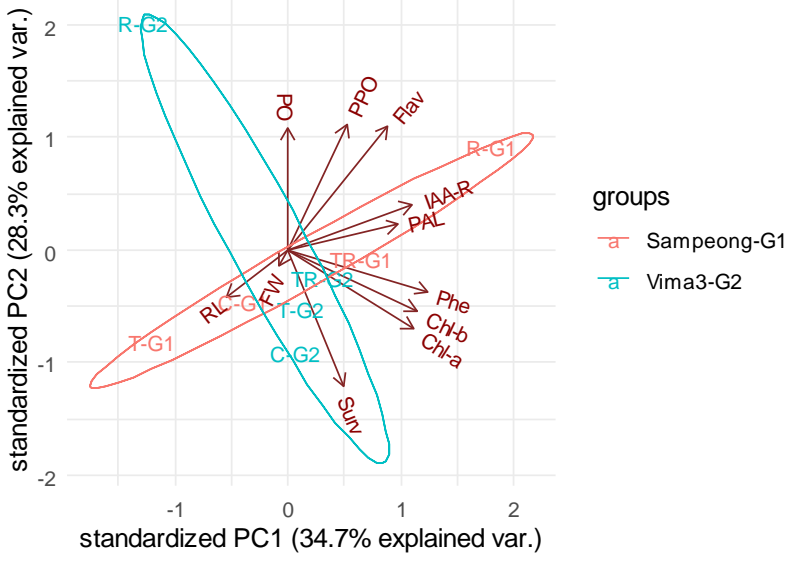

Figure 8. The ggbiplot of principal component analysis of the production of plant defense-related enzymes on mungbean induced resistance against Rhizoctonia solani. Surv number of plant survive, RL roots length, FW total fresh weight, PO peroxidase, PPO polyphenol oxidase, PAL phenylalanine ammonia-lyase, Phe Phenolic content, Flav flavonoid content, IAA-R IAA-synthase from roots, Chl-a chlorophyll a, Chl-b chlorophyll b

Mungbean which is pretreated with $T$. virens and together with the exposure to pathogens showed increase in levels of some defense-related compounds such as peroxidase, PAL, phenolic, and flavonoid. Other than direct action, induction of mungbean resistance by $T$. virens involved the synthesis higher plant growth promoter compounds such as phytohormone (IAA), and chlorophyll content. In mungbean- $R$. solani- $T$. virens interaction, the absence of pathogen has important role in inducing plant defense response. Our study showed that along with induction of IAA-synthase in roots, accumulation of phenolics and flavonoid was observed which indicated that $T$. virens treatment could induce the plant defense response in mungbean seedling, however, it's not fully expressed. Van der Ent et al. (2009) explained sometimes defense responses are not directly activated, but need period of time to accelerate upon attack by pathogens. For example, the resistance of tomato induced by $T$. harzianum to late blight appeared after 90 to 120 days, and over 2 years, the reduction of the disease was up to $80 \%$. In conclusion, $T$. virens strain Tv4 treatment could induce the mungbean defense response against $R$. solani directly and indirectly. Direct induction showed by the increased activity of some defense-related enzymes such as peroxidase, total phenolic, and flavonoid, following the phenylpropanoid pathway. Indirectly, $T$. virens treatment was able to improve photosynthetic performance and promote mungbean growth which positively correlated to the accumulation of plant defense-related enzymes.

\section{ACKNOWLEDGEMENTS}

The author would like to thank the Indonesian Agency for Agricultural Research and Development (IAARD) for financially supported of this research, and Yulius Eka Laxmana Samba for helping in instrument preparation.

\section{REFERENCES}

Adhilakshmi M, Paranidharan V, Balachandar D, Ganesamurthy K, Velazhahan R. 2014. Suppression of root rot of mung bean (Vigna radiata L.) by Streptomyces $\mathrm{sp}$. is associated with induction of peroxidase and polyphenol oxidase. Arch Phytopathol Plant Prot 47 (5): 71-583

Angel LPL, Yusof MT, Ismail IS, Ping BTY, Azni INAM, Kamarudin NH, Sundram S. 2016. An in vitro study of the antifungal activity of Trichoderma virens $7 \mathrm{~b}$ and a profile of its non-polar antifungal components released against Ganoderma boninense. J Microbiol 54 (11): 732-744.

Ata A, El-Samman M, Moursy MA, Mostafa M. 2008. Inducing resistance against rust disease of sugar beet by certain chemical compounds. Egypt J Phytopathol 36: 113-132.

Bekkara F, Jay M, Viricel MR, Rome S. 1998. Distribution of phenolic compounds within seed and seedlings of two Vicia faba cvs differing in their seed tannin content, and study of their seed and root phenolic exudations. J Plant Soil 203 (1): 27-36.

Bengyella L, Waikhom SD, Allie F, Rey, C. 2015. Virus tolerance and recovery from viral induced-symptoms in plants are associated with transcriptome reprogramming. Plant Mol Biol 89 (3): 243-252.

Bhattacharya A, Sood P, Citovsky V. 2010. The roles of plant phenolics in defense and communication during Agrobacterium and Rhizobium infection. J Mol Plant Pathol 11 (5): 705-719.

Castillejo MA, Bani M, Rubiales D. (2015). Understanding pea resistance mechanisms in response to Fusarium oxysporum through proteomic analysis. Phytochemistry 115: 44-58. DOI: 10.1016/j.phytochem.2015.01.009

Constabel CP, Barbehenn R. 2008. Defensive roles of polyphenol oxidase in plants. In Schaller A. (eds) Induced Plant Resistance to Herbivory. Springer. Dordrecht.

Contreras-Cornejo HA, Macías-Rodríguez L, Cortés-Penagos C, LópezBucio J. 2009. Trichoderma virens, a plant beneficial fungus, enhances biomass production and promotes lateral root growth through an auxin-dependent mechanism in Arabidopsis. Plant hysiol 149 (3): 1579-1592.

Dogbo D, Gogbeu S, N'zue B, Ya K, Zohouri G, Mamyrbekova-Bekro J, Bekro YA. 2012. Comparative activities of phenylalanine ammonialyase and tyrosine ammonia-lyase and phenolic compounds accumulated in cassava elicited cell. Afr Crop Sci J 20 (2): 85-94.

Duba A, Goriewa-Duba K, Wachowska U, Głowacka K, Wiwart M. 2019. The Associations between leaf morphology, Phenylalanine Ammonia Lyase activity, Reactive Oxygen Species, and Fusarium resistance in selected species of wheat with different ploidy levels. Plants 8 (10): 360.

Dubey SC, Tripathi A, Tak R. 2018. Expression of defense-related genes in mung bean varieties in response to Trichoderma virens alone and in the presence of Rhizoctonia solani infection. Biotech 8 (10): 432. DOI: $10.1007 / \mathrm{s} 13205-018-1453-2$.

Durairaj K, Velmurugan P, Park JH, Chang WS, Park YJ, Senthilkumar P. 2018. Characterization and assessment of two biocontrol bacteria against Pseudomonas syringae wilt in Solanum lycopersicum and its genetic responses. Microbiol Res 206: 43-49. DOI: 10.1016/j.micres.2017.09.003

Harman GE. 2011. Multifunctional fungal plant symbionts: new tools to enhance plant growth and productivity. New Phytol 189 (3): 647-649.

Harman GE., Herrera-Estrella, A. H., Horwitz, B. A., Lorito, M. 2012. Trichoderma-from basic biology to biotechnology. J Microbiol 158 (1): 1 .

Harman GE., Howell, C. R., Viterbo, A., Chet, I., Lorito, M. 2004. Trichoderma species - opportunistic, avirulent plant symbionts. Nat Rev Microbiol 2: 43. DOI: 10.1038/nrmicro797 
Hermosa R, Viterbo A, Chet I, Monte E. 2012. Plant-beneficial effects of Trichoderma and of its genes. J Microbiol 158 (1): 17-25.

Hoagland RE. (1990). Biochemical responses of plants to pathogens. In R. E. Hoagland (eds), Microbes and Microbial Products as Herbicides ACS Publications. Stoneville, US.

Howell C. 2003. Mechanisms employed by Trichoderma species in the biological control of plant diseases: the history and evolution of current concepts. Plant Dis 87 (1): 4-10.

Howell C, Stipanovic R, Lumsden R. 1993. Antibiotic production by strains of Gliocladium virens and its relation to the biocontrol of cotton seedling diseases. Biocontrol Sci Technol 3 (4): 435-441.

Howell CR. 2006. Understanding the mechanisms employed by Trichoderma virens to effect biological control of cotton diseases. Phytopathology 96 (2): 178-180.

Kangasjärvi S, Neukermans J, Li S, Ar EM, Noctor G. 2012. Photosynthesis, photorespiration, and light signalling in defense responses. J Exp Bot 63 (4): 1619-1636. DOI: 10.1093/jxb/err402

Kavitha R, Umesha S. 2008. Regulation of defense-related enzymes associated with bacterial spot resistance in tomato. Phytoparasitica 36 (2): 144 .

Kubalt K. 2016. The role of phenolic compounds in plant resistance. Biotechnol Food Sci 80 (2): 97-108.

Lichtenthaler HK, Buschmann C. 2001. Chlorophylls and carotenoids: Measurement and characterization by UV-VIS spectroscopy. Curr Protoc Food Anal Chem 1 (1): F4. 3.1-F4. 3.8.

Løvdal T, Olsen KM, Slimestad R, Verheul M, Lillo C. 2010. Synergetic effects of nitrogen depletion, temperature, and light on the content of phenolic compounds and gene expression in leaves of tomato. Phytochemistry 71 (5-6): 605-613.

Mahanta IBAR. 2012. Evaluation of peroxidases from various plant sources. Curr Protoc Food Anal Chem 2 (5): 1-5.

Małolepsza U, Nawrocka J, Szczech M. 2017. Trichoderma virens 106 inoculation stimulates defense enzyme activities and enhances phenolic levels in tomato plants leading to lowered Rhizoctonia solani infection. Biocontrol Sci Technol 27 (2): 180-199.

Mandal SM, Chakraborty D, Dey S. 2010. Phenolic acids act as signaling molecules in plant-microbe symbioses. Plant Signal Behav 5: 359368.

Martínez-Medina A, Alguacil MDM, Pascual JA, Van Wees SC. 2014 Phytohormone profiles induced by Trichoderma isolates correspond with their biocontrol and plant growth-promoting activity on melon plants. J Chem Ecol 40 (7): 804-815.

Martínez-Medina A, Fernández I, Sánchez-Guzmán MJ, Jung, SC, Pascua JA, Pozo MJ. 2013. Deciphering the hormonal signalling network behind the systemic resistance induced by Trichoderma harzianum in tomato. Front Plant Sci 4: 206.

Martínez-Medina A, Roldán A, Albacete A, Pascual JA. 2011. The interaction with arbuscular mycorrhizal fungi or Trichoderma harzianum alters the shoot hormonal profile in melon plants. Phytochemistry 72 (3): 223-229.

Mazzei P, Vinale F, Woo SL, Pascale A, Lorito M, Piccolo A. 2016 Metabolomics by H-HRMAS-NMR of tomato plants treated with two secondary metabolites isolated from Trichoderma. J Agric Food Chem 64: 1021-1055.

Moharan S, Dutta S. 2016. Spatial variability of chlorophyll and nitrogen content of rice from hyperspectral imagery. ISPRS J Photogramm 122: $17-29$

Mukherjee M, Mukherjee PK, Horwitz B A, Zachow C, Berg G, Zeilinger S. 2012. Trichoderma-plant-pathogen interactions: advances in genetics of biological control. Indian J Microbiol 52: 522-529. DOI 10.1007/s12088-012-0308-5

Pérez-Bueno ML, Pineda M, Barón M. 2019. Phenotyping plant responses to biotic stress by chlorophyll fluorescence imaging. Front Plant Sci 10: 1135. DOI: 10.3389/fpls.2019.01135

Phelps RH, Sequeira L. 1967. Synthesis of indoleacetic acid via tryptamine by a cell-free system from tobacco terminal buds. Plant Physiol 42 (8): 1161.

Pieterse CMJ, Zamioudis C, Berendsen RL, Weller DM, Van Wees SCM, Bakker PAHM. 2014. Induced systemic resistance by beneficial microbes. Ann Rev Phytopathol 52 (1): 347-375. DOI: 10.1146/annurev-phyto-082712-102340

Shakeri J Foster HA. 2007. Proteolytic activity and antibiotic production by Trichoderma harzianum in relation to pathogenicity to insects. Enzyme Microb Technol 40 (4): 961-968.

Solekha R, Susanto FA, Joko T, Nuringtyas TR, Purwestri YA. 2019. Phenylalanine ammonia-lyase (PAL) contributes to the resistance of black rice against Xanthomonas oryzae pv. oryzae. J Plant Pathol, DOI: $10.1007 / \mathrm{s} 42161-019-00426-\mathrm{z}$.

Shoresh M, Harman GE. 2008. The molecular basis of shoot responses of maize seedlings to Trichoderma harzianum T22 inoculation of the root: a proteomic approach. J Plant Physiol 147 (4): 2147-2163.

Shoresh M, Harman GE. 2010. Differential expression of maize chitinases in the presence or absence of Trichoderma harzianum strain T22 and indications of a novel exo-endo-heterodimeric chitinase activity. BMC Plant Biol 10 (1): 136. DOI: 10.1186/1471-2229-10-136.

Shoresh M, Yedidia I, Chet I. 2005. Involvement of jasmonic acid/ethylene signaling pathway in the systemic resistance induced in cucumber by Trichoderma asperellum T203. Phytopathology 95 (1): 76-84.

Singh B, Singh A, Singh B, Singh H. 2014. Trichoderma harzianum elicits induced resistance in sunflower challenged by Rhizoctonia solani. J App Microbiol 116 (3): 654-666.

Surekha C, Neelapu N, Prasad BS, Ganesh PS. 2014. Induction of defense enzymes and phenolic content by Trichoderma viride in Vigna mungo infested with Fusarium oxysporum and Alternaria alternata. J Intl J Agr Sci Res 4 (4): 31-40.

Team RJR, Inc, Boston MA. http: //www. rstudio. com. 2010. RStudio: integrated development for R. 42, 14.

Thakker JN, Patel S, Dhandhukia PC. 2012. Induction of defense-related enzymes in banana plants: Effect of live and dead pathogenic strain of Fusarium oxysporum f. sp. cubense. J ISRN Biotechnol 2013. DOI: $10.5402 / 2013 / 601303$

Treutter D. 2005. Significance of flavonoids in plant resistance and enhancement of their biosynthesis. Plant Biol 7: 581-591.

Tucci M, Ruocco M, De Masi L, De Palma, M, Lorito M. 2011. The beneficial effect of Trichoderma spp. on tomato is modulated by the plant genotype. Mol Plant Pathol 12 (4): 341-354.

Van der Ent S, Van Wees SC, Pieterse CM. 2009. Jasmonate signaling in plant interactions with resistance-inducing beneficial microbes. Phytochemistry 70 (13-14): 1581-1588.

Whipps JM, \& Lumsden RD. 2001. Commercial use of fungi as plant disease biological control agents: status and prospects. In Butt T.M, Jacson C, N. Magan (eds). Fungal biocontrol agents: progress, problems and potential. CABI Pub. Wallingford, UK

Woo S, Scala F, Ruocco M, Lorito M. 2006. The molecular biology of the interactions between Trichoderma spp., phytopathogenic fungi, and plants. Phytopathology 96 (2): 181-185.

Wu Q, Sun R, Ni M, Yu J, Li Y, Yu C, Chen J. 2017. Identification of a novel fungus, Trichoderma asperellum GDFS1009, and comprehensive evaluation of its biocontrol efficacy. PLoS One 12: 1103 e0179957. DOI: 10.1371/journal.pone.0179957

Yedidia I, Shoresh M, Kerem Z, Benhamou N, Kapulnik Y, Chet I. 2003. Concomitant induction of systemic resistance to Pseudomonas syringae pv. lachrymans in cucumber by Trichoderma asperellum (T203) and accumulation of phytoalexins. J Appl Environ Microbiol 69 (12): 7343-7353.

Yusnawan E, Inayati A, Baliadi Y. 2019. Effect of soybean seed treatment with Trichoderma virens on its growth and total phenolic content. In Romaidi et al. (eds) Proceeding of International Conference of Biology and Applied Science (ICOBAS), The State Islamic University of Maulana Malik Ibrahim, Malang 13-14 March 2019. [Indonesian]

Zhang F, Ge H, Zhang F, Gu, N, Wang Y, Chen L, Li C. 2016. Biocontrol potential of Trichoderma harzianum isolates T-aloe against Sclerotinia sclerotiorum in soybean. Plant Physiol Biochem 100: 6474. 